\title{
F and Type 1 Piliation of Escherichia coli
}

\author{
By CHRISTOF K. BIEBRICHER* AND EVA-MARIA DÜKER \\ Max-Planck-Institut für Biophysikalische Chemie, D-34 Göttingen, FRG
}

(Received 29 April 1983; revised 3 November 1983)

\begin{abstract}
F and type 1 piliation of various Escherichia coli $\mathrm{K} 12 \mathrm{Hfr}$ and $\mathrm{F}^{+}$strains was re-examined by using a new visualization assay. In anaerobic cultures in rich media, bacteria were well $F$ piliated throughout all growth phases. In aerobic cultures in rich media, F piliation reached a maximum in the mid-exponential phase. The yield of pili was up to $15 \mathrm{mg}^{-1}$. In aerated cultures, $F$ pili disappeared in the late exponential phase. In rich media $F$ pili were on average 10-20 $\mu \mathrm{m}$ long; in synthetic media they were an order of magnitude shorter, and less numerous. Addition of metabolic poisons $\left(\mathrm{NaCN}, \mathrm{NaN}_{3}, \mathrm{Na}_{3} \mathrm{AsO}_{4}\right.$, phenylethyl alcohol) and starving the bacteria caused rapid disappearance of $F$ pili under aerobic conditions, but had no influence on F piliation under anaerobic conditions. Type 1 piliation was not influenced by these drugs or by an alteration of growth conditions.
\end{abstract}

\section{INTRODUCTION}

The occurrence of F pili and type 1 pili on the surface of Escherichia coli $\mathrm{K} 12$ is obviously a regulated process. Maccacaro (Maccacaro \& Turri, 1959) and others (Swaney et al., 1977; Brinton, 1965; Eisenstein et al., 1981) have described loss and gain of the common type 1 pili (fimbriae) under different conditions. F piliation also changes markedly under different growth conditions (Novotny \& Lavin, 1972; Stallions \& Curtiss, 1972) or during treatment of piliated cells with certain drugs (Novotny et al., 1972; Novotny \& Fives-Taylor, 1974; O'Callaghan et al., 1973; Wendt \& Mobach, 1968). However, the mechanisms regulating $F$ and type 1 piliation are unknown and some of the phenomena which have been described in the past require re-examination under more closely defined growth conditions. The visualization assay described in the accompanying paper (Biebricher \& Düker, 1984) was used to determine F pili concentration profiles under different growth conditions, to study the effects of drugs on $\mathrm{F}$ and type 1 piliation, and to follow the purification to homogeneity of $F$ and type 1 pili from different strains of E. coli.

\section{METHODS}

Strains of E. coli. Strains Hfr Hayes (ATCC 23739), Hfr Cavalli (ATCC 25256) and K 12 F'lac (ATCC 23725) were obtained from the American Type Culture Collection. Strain UB1025 (lac leu str $\mathrm{fla}$ ) was obtained from Dr J. B. Beard (Beard et al., 1972) and used as host of F'lac. Strain M1381 (str thy gal his arg F'lac) was obtained from Dr M. Achtman (Helmuth \& Achtman, 1978). This strain does not have type 1 pili. Strain $\mathrm{K}_{12} 1200 \mathrm{~F}^{+}\left(r n a, s u_{11}\right)$ was obtained from Dr H. Hoffmann-Berling (Dürwald \& Hoffmann-Berling, 1968).

Media. These are described in the accompanying paper (Biebricher \& Düker, 1984).

Preparation of $F$ and type 1 pili. The preparation procedure made use of many steps described in previous reports (Brinton, 1965; Beard et al., 1972; Minkley et al., 1976; Date et al., 1977; Helmuth \& Achtman, 1978; Tomoeda et al., 1975; Korhonen et al., 1980). Bacteria were grown in 201 rich medium in a New Brunswick fermenter at $37^{\circ} \mathrm{C}$ to an $\mathrm{OD}_{660}$ of 5.0 (late exponential phase). Aeration was regulated by an oxygen electrode to maintain $60 \%$ to $80 \%$ oxygen saturation (air-saturated medium taken as $100 \%$ ). The medium was chilled to $0{ }^{\circ} \mathrm{C}$ by the addition of $10 \mathrm{~kg}$ ice to the culture and the bacteria were harvested by centrifugation $(10000 \mathrm{~g}, 10 \mathrm{~min})$. The bacteria $(200 \mathrm{~g}$ wet weight) were suspended in $200 \mathrm{~g} 60 \%$ (w/w) sucrose solution in $0.02 \mathrm{M}$-Tris/ $\mathrm{HCl}$ buffer $(\mathrm{pH} 7 \cdot 5)$ with the help of a blender operated at very low speed. The bacteria were sedimented by centrifugation $(15000 \mathrm{~g}, 15 \mathrm{~min})$; the supernatant was then diluted to $500 \mathrm{ml}$ with $0.02 \mathrm{M}-\mathrm{Tris} / \mathrm{HCl}(\mathrm{pH} 7.5)$ and cleared again by centrifugation (stage 
A). To this solution were added, with gentle stirring with a glass rod: $15 \mathrm{~g} \mathrm{NaCl}, 30 \mathrm{ml}$ of a solution of $20 \%$ (w/w) Dextran T 500 and $100 \mathrm{ml}$ of a $30 \%(\mathrm{w} / \mathrm{w})$ solution of polyethylene glycol $6000 ; 15 \mathrm{~min}$ after mixing, the phases were separated by low-speed centrifugation $(10000 \mathrm{~g}, 10 \mathrm{~min})$. The lower (Dextran) phase was collected and diluted to $100 \mathrm{ml}$ with Tris-saline buffer $(0 \cdot 02 \mathrm{M}$-Tris $/ \mathrm{HCl}, \mathrm{pH} 7 \cdot 5,0 \cdot 1 \mathrm{M}-\mathrm{NaCl})$ after which $100 \mu 11 \mathrm{M}-\mathrm{MgSO}_{4}$ and $100 \mu \mathrm{g}$ DNAase (Boehringer-Mannheim, grade I) were added. The solution was gently stirred until its viscosity was reduced. The pseudocrystalline pili aggregates were collected by centrifugation $(10000 \mathrm{~g}, 15 \mathrm{~min})$ and the turbid supernatant was discarded. The aggregates were dissolved over a period of 2 to $15 \mathrm{~h}$ in $200 \mathrm{ml} 30 \%$ ( w/w) sucrose solution in Tris-saline buffer. The solution was cleared of residual bacterial debris by high speed centrifugation $(20000 \mathrm{~g}, 25 \mathrm{~min})$ before the pili were precipitated by addition of $50 \mathrm{ml} \mathrm{30 \%}(\mathrm{w} / \mathrm{w})$ polyethylene glycol 6000 and collected by centrifugation. The aggregates were dissolved in $20 \mathrm{ml} 7 \mathrm{M}$-urea in Tris-saline buffer (stage B) and cleared again by centrifugation $(25000 \mathrm{~g}, 20 \mathrm{~min})$. This solution was diluted with $40 \mathrm{ml}$ of Tris-saline buffer, loaded on top of a density gradient produced by overlayering $7 \mathrm{~g}$ each of $70 \%, 60 \%, 50 \%$ and $40 \%(\mathrm{w} / \mathrm{w})$ sucrose solution in Tris-saline buffer and centrifuged for $64 \mathrm{~h}$ at 48000 r.p.m., $280000 \mathrm{~g}$, at $10^{\circ} \mathrm{C}$ in a Beckman type 50.2 rotor or a Kontron TFT 65.38 rotor. The gradient was collected in fractions; the F and type 1 pili peaks were located by the visualization assay of an appropriately diluted sample, and pooled. The purity of pili preparations was found to be over $95 \%$ by means of electron microscopy, gel electrophoresis and amino acid analysis.

Growth of bacteria. Anaerobic cultures were grown in $10 \mathrm{ml}$ medium in $16 \mathrm{~mm}$ diameter test tubes, or in $50 \mathrm{ml}$ medium in $50 \mathrm{ml}$ Erlenmeyer bottles. Aerobic cultures were grown in $10 \mathrm{ml}$ medium in $50 \mathrm{ml}$ Erlenmeyer flasks, or in $50 \mathrm{ml}$ medium in $250 \mathrm{ml}$ Kluyver flasks with vigorous shaking. The $\mathrm{OD}_{660}$ of appropriately diluted bacterial cultures was determined in a Zeiss PMQ2 spectrophotometer and converted into bacterial concentration by means of a calibration curve.

Quantifying $F$ piliation. F piliation was monitored by the visualization assay described in the accompanying paper (Biebricher \& Düker, 1984). Bacteria carrying 0, 1, 2, 3,4 or more pili, and free pili, were counted separately. Approximately 100 (but not less than 50 ) bacteria were counted and the average number of pili per cell was determined. Free $F$ pili were counted as being attached to bacteria in this calculation. The average length of $F$ pili was calculated from measurements made with a micrometer grid in the Zeiss IM35 microscope. The average combined length of $F$ pili per bacterium was multiplied by the bacterial concentration and the unit mass of the $F$ pili, assuming the mass of $1 \mu \mathrm{m}$ of $\mathrm{F}$ pilus to be $1 \times 10^{-16} \mathrm{~g}$ (a cylinder with a diameter of $10 \mathrm{~nm}$ and a density of $\left.1 \cdot 3 \mathrm{~g} \mathrm{~cm}^{-3}\right)$ to give the concentration of pilin per litre of culture.

Treatment of bacteria with drugs. Bacteria $\left(\mathrm{Hfr} \mathrm{H}\right.$ and $\left.1200 \mathrm{~F}^{+}\right)$were grown in rich medium under aerobic or anaerobic conditions (see above) to a cell density of $5 \times 10^{8} \mathrm{ml}^{-1}$. Samples $(9 \mathrm{ml})$ of the cultures were transferred to tubes (anaerobic) or flasks (aerobic) containing $1 \mathrm{ml}$ of a 10 -fold concentration of the drug. Incubation was continued for $3 \mathrm{~h}$ at $37^{\circ} \mathrm{C}$, and $\mathrm{F}$ and type 1 piliation was monitored by the visualization assay. Viability tests of the cultures after $2 \mathrm{~h}$ incubation in the presence of drugs (determined by plating) showed that the cells survived drug treatment (except for arsenate treatment under anaerobic conditions). Starvation of bacteria was achieved by centrifuging exponentially growing bacterial cultures and resuspending them in $0 \cdot 15 \mathrm{M}-\mathrm{NaCl}$, and the piliation was monitored over a starvation period of $3 \mathrm{~h}$.

Amino acid analysis. Samples of pili were freed from sucrose by several precipitations with $50 \%$ ethanol and lyophilized. For hydrolysis, lyophilized samples were dissolved in $6 \mathrm{M}-\mathrm{HCl}, 14 \mathrm{~mm}$-mercaptoethanol and heated in vacuo for $24 \mathrm{~h}$ at $110^{\circ} \mathrm{C}$. The hydrolysates were dried in vacuo over KOH and run in a Biotronic LC $6000 \mathrm{E}$ amino acid analyser. Cysteine and methionine were determined from samples oxidized with performic acid (Moore, 1963) and lyophilized prior to hydrolysis. Tryptophan was determined in samples hydrolysed in alkali (Drèze, 1960). The amino acid compositions of $F$ and type 1 pili of the strains mentioned did not show strain-specific differences and agreed with the values reported by others (Brinton, 1965, 1971).

SDS-polyacrylamide gel electrophoresis. This was performed in $17 \%$ acrylamide gels according to Laemmli (1970). For quantitative disintegration of type 1 pili, formic acid treatment was required as follows. Samples containing type 1 pili were diluted with an excess of ice-cold $5 \%(w / v)$ TCA solution. The precipitate was collected by centrifugation $(6000 \mathrm{~g}, 10 \mathrm{~min})$, washed with acetone and dried. The residue was dissolved (to a concentration of $1 \mathrm{mg} \mathrm{ml}^{-1}$ or less) in $95 \%$ ice-cold formic acid, incubated for $15 \mathrm{~min}$ at $0{ }^{\circ} \mathrm{C}$, and lyophilized. The residue was dissolved in SDS-sample buffer as described by Laemmli (1970).

Other techniques are described in the accompanying paper (Biebricher \& Düker, 1984).

\section{RESULTS}

\section{Piliation of bacteria under different growth conditions}

The visualization assay described in the accompanying paper (Biebricher \& Düker, 1984) allowed easy monitoring of the degree of piliation. A comparison of different $\mathrm{Hfr}$ and $\mathrm{F}^{+}$strains ( $\mathrm{Hfr} \mathrm{H}, \mathrm{Hfr} \mathrm{C}, 1200 \mathrm{~F}^{+}$, UB1025 $\mathrm{F}^{\prime} \mathrm{lac}$ ) revealed little difference in F piliation (Brinton \& Beer, 1967) where growth conditions were identical. However, the growth conditions had a great 
Table 1. F piliation of bacteria under different growth conditions

\begin{tabular}{|c|c|c|c|c|}
\hline Medium & Aeration & Growth phase & $\begin{array}{l}\text { Average } \\
\text { no. of pili } \\
\text { per cell }\end{array}$ & $\begin{array}{l}\text { Average } \\
\text { length of pili } \\
\qquad(\mu \mathrm{m})\end{array}$ \\
\hline Rich & Aerobic & $\begin{array}{l}\text { Early exponential }\left(\mathrm{OD}_{660} 0 \cdot 3\right) \\
\text { Mid-exponential }\left(\mathrm{OD}_{660} 3 \cdot 0\right) \\
\text { Late exponential }\left(\mathrm{OD}_{660} 7 \cdot 0\right) \\
\text { Stationary }(24 \mathrm{~h})\end{array}$ & $\begin{array}{c}2-3 \\
3-4 \\
\text { decreasing } \\
0.05\end{array}$ & $\begin{array}{c}5-10 \\
10-20 \\
2-5 \\
2-5\end{array}$ \\
\hline & Anaerobic & $\begin{array}{l}\text { Early exponential }\left(\mathrm{OD}_{660} 0 \cdot 3\right) \\
\text { Late exponential }\left(\mathrm{OD}_{660} 1 \cdot 0\right) \\
\text { Stationary }(24 \mathrm{~h})\end{array}$ & $\begin{array}{l}3-4 \\
3-4 \\
2-3\end{array}$ & $\begin{array}{l}15-25 \\
15-25 \\
15-25\end{array}$ \\
\hline Synthetic & Aerobic & $\begin{array}{l}\text { Early exponential }\left(\mathrm{OD}_{660} 0 \cdot 3\right) \\
\text { Mid-exponential }\left(\mathrm{OD}_{660} 1 \cdot 0\right) \\
\text { Late exponential }\left(\mathrm{OD}_{660} 3 \cdot 0\right) \\
\text { Stationary }(24 \mathrm{~h})\end{array}$ & $\begin{array}{c}2 \\
1 \\
\text { decreasing } \\
<0.02\end{array}$ & $\begin{array}{l}1-2 \\
1-5 \\
1-5 \\
1-5\end{array}$ \\
\hline & Anaerobic & All phases & $<0.02$ & - \\
\hline
\end{tabular}

influence on the number of F pili per cell and their lengths (Table 1). In agreement with Curtiss et al. (1969) and Stallions \& Curtiss (1972) cells grown anaerobically in rich media had more and longer pili than cells grown under aerobic conditions. The pili we observed, however, were considerably longer than those reported previously (Curtiss et al., 1969).

The average length and the average number of $F$ pili per bacterium changed during the different growth phases of aerated cultures. In the early exponential phase in rich media, bacteria typically had two $\mathrm{F}$ pili 5 to $10 \mu \mathrm{m}$ long. $\mathrm{F}$ piliation in the bacterial population was remarkably uniform in this growth phase, with little deviation from these values. As the culture reached the mid-exponential phase, the number of pili per cell and their length increased; organisms became heterogeneous with respect to piliation. Some bacteria were found with as many as 10 long pili, while others had only two. Abnormally long pili ( 30 to $50 \mu \mathrm{m})$ were observed occasionally. In the late exponential phase, where shortage of oxygen limits growth, the concentration of pili and their lengths decreased rapidly (Brinton \& Beer, 1967; Beard et al., 1972). The bacteria did not enter the stationary phase synchronously and the population was quite heterogeneous with respect to piliation. Many cells were totally devoid of $F$ pili, while others still carried numerous pili. Motility was strong in this phase. There was a net loss of F pili during the late exponential phase since the number of free pili did not increase. The pili were therefore neither broken nor shed from the bacterial surface.

Aerated cultures of bacteria in a synthetic medium supplemented with Casamino acids also showed strong $\mathrm{F}$ piliation. About $90 \%$ of all bacteria in the early exponential phase had two pili, others had one or three pili. However, the average length of the pili (about $1 \mu \mathrm{m})$ was less than that of the pili in rich media. In the mid-exponential phase, a few longer pili could be found (up to approximately $5 \mu \mathrm{m}$ long) but the number of pili per cell decreased. In the late exponential phase the pili disappeared rapidly, as was observed in rich media.

Under anaerobic conditions, the degree of $F$ piliation was constant during all growth phases. In synthetic media, where growth was very slow under anaerobic conditions, few pili could be found. However, in rich media the degree of piliation was high under anaerobic conditions. In all growth phases, three or four quite long pili per cell were observed. The bacteria retained their pili when they entered the stationary growth phase (Ippen \& Valentine, 1965; Brinton \& Beer, 1967) and often formed quite large aggregates (Fig. 1; Helmuth \& Achtman, 1978) interconnected by very many $F$ and type 1 pili. The number of pili per cell in the aggregates could not be accurately determined but appeared similar to that of single bacteria.

Using the visualization assay, quantitative estimates of $F$ piliation were made. From the cell density, the average length of the $F$ pili and their number per cell, the concentration of $F$ pilin in growing bacterial cultures was calculated (Fig. 2). At high cell densities, all the $\mathrm{F}^{+}$and $\mathrm{Hfr}$ strains investigated showed a high degree of $F$ piliation. Large concentrations of $F$ pili could thus be obtained under conditions favouring high cell densities. These include rich media, 

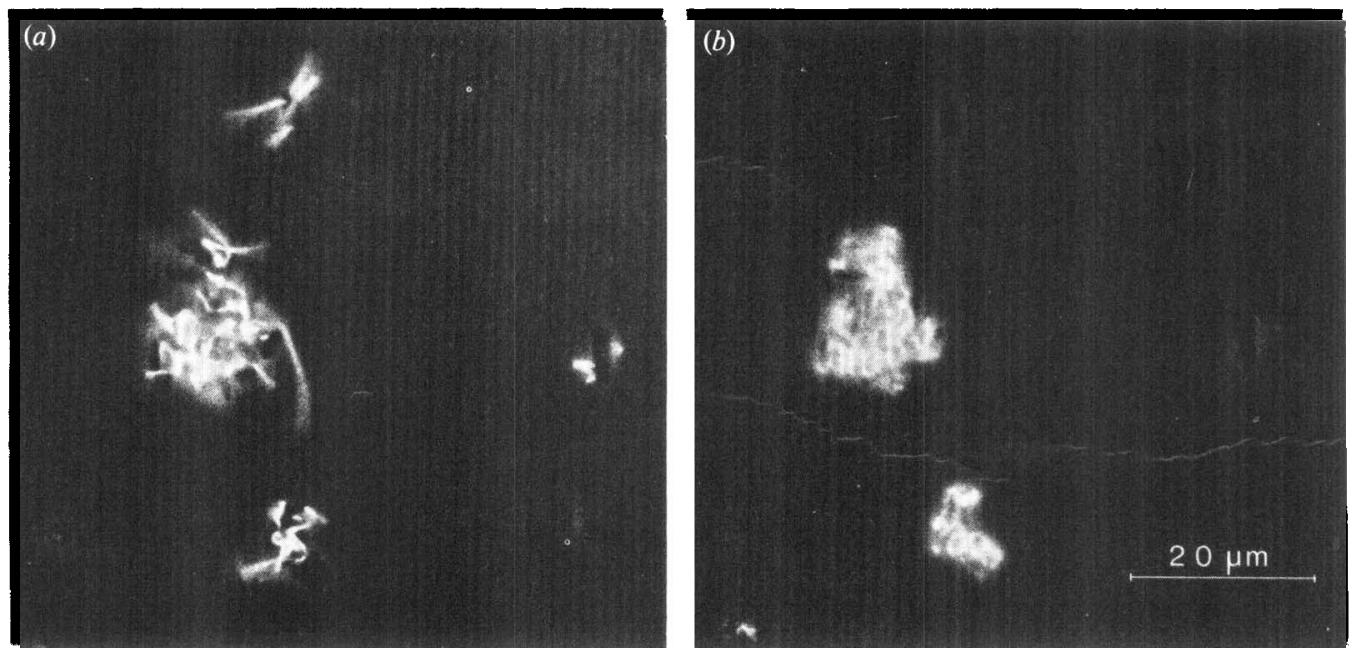

Fig. 1. Bacterial aggregates in the stationary phase in anaerobic culture $\left(E\right.$. coli $1200 \mathrm{~F}^{+}$grown overnight in rich medium under anaerobic conditions). Conditions for visualization were as described in the accompanying paper (Biebricher \& Düker, 1984). (a) Incident light excitation with green light and phase-contrast showing F piliation; $(b)$ incident light excitation with blue light and phase-contrast showing type 1 piliation.
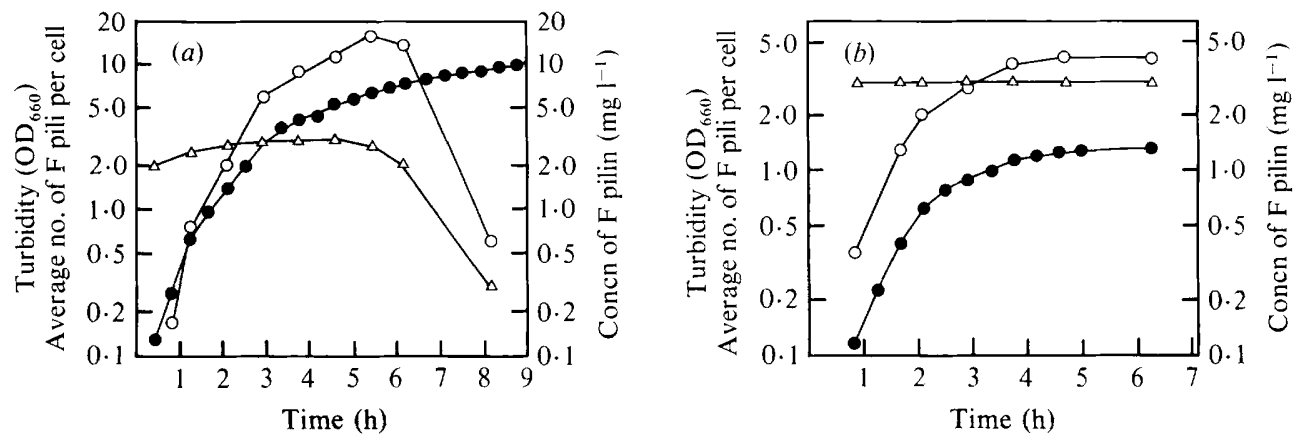

Fig. 2. Concentration of $\mathbf{F}$ pili in cultures of $E$. coli $\mathbf{H f r} \mathbf{H}$ growing in rich medium $(a)$ aerobically and (b) anaerobically. Turbidity of the culture, measured as $\mathrm{OD}_{660} ; \triangle$, average number of $\mathrm{F}$ pili per cell; $O$, concentration of $F$ pilin per litre of medium calculated from the number and the length of the pili.

maximum aeration, and controlled pH, (Fig. 2a). Due to the rapid disappearance of F pili at the beginning of the stationary phase of growth; there was a sharp maximum of $F$ piliation late in the exponential growth phase. Under anaerobic conditions, despite the somewhat higher number of $F$ pili per cell, their maximum concentration was considerably reduced due to the much lower cell densities obtained (Fig. $2 b$ ). The concentration of $\mathrm{F}$ pili found in synthetic media was several orders of magnitude lower than that found in rich media, due to the reduced number of $\mathrm{F}$ pili, their shorter length and the lower cell densities.

\section{Effect of drugs on F piliation}

Many groups have reported a strong influence of drugs on $F$ piliation of bacteria. We re-examined some of these effects. A culture grown in rich medium was divided into samples containing either $10^{-2} \mathrm{M}-\mathrm{NaCN}$ (Novotny et al., 1972; Novotny \& Fives-Taylor, 1974), $0 \cdot 1 \mathrm{M}-\mathrm{Na}_{3} \mathrm{AsO}_{4}$ (O'Callaghan et al., 1973), $1 \% \mathrm{NaN}_{3}$ (O'Callaghan et al., 1973) or $0.1 \%$ phenylethyl alcohol (Wendt \& Mobach, 1968) and incubated under aerobic and under anaerobic conditions. $\mathrm{F}$ piliation was monitored with the fluorescence assay at various times. 
Under anaerobic conditions no pronounced loss of $\mathrm{F}$ pili was observed, contrasting with previous reports (Novotny et al., 1972; Novotny \& Fives-Taylor, 1974; O'Callaghan et al., 1973; Wendt \& Mobach, 1968). Indeed, no differences were detected from untreated cultures over a period of $3 \mathrm{~h}$. However, after exposure to arsenate for $1 \mathrm{~h}$ the $\mathrm{F}$ pili disappeared and the cells lysed after 3 to $4 \mathrm{~h}$. Starvation of the cells in $0.15 \mathrm{M}-\mathrm{NaCl}$ or cooling of the culture to $25^{\circ} \mathrm{C}$ (Novotny \& Lavin, 1971) also had no effect on F piliation under anaerobic conditions. Bacteria growing at $25^{\circ} \mathrm{C}$ in rich medium under anaerobic conditions were well piliated, carrying two or three $F$ pili with an average length of about $10 \mu \mathrm{m}$.

Under aerobic conditions, however, treatment with drugs or starving the bacteria resulted in the disappearance of $F$ pili from the bacterial surface. We observed the same phenomenon with cells entering the stationary phase. Drug-induced arrest of bacterial growth thus showed the same F piliation phenomena as the arrest of growth due to the limitation of resources.

\section{Type 1 piliation under different growth conditions}

The immunofluorescence assay of type 1 pili (see accompanying paper; Biebricher \& Düker, 1984) was suitable for rapid screening of type 1 piliation of bacteria. However, quantitative determination of type 1 pili was not possible, because the majority of the type 1 pili were not resolved in the microscope due to their short length and their high number per cell. The regulation of production of type 1 pili was completely independent of $F$ pili regulation. The proportion of cells carrying type 1 pili (usually about $30 \%$ ) was constant during the whole growth period of the bacteria. The effects of changes in medium composition and conditions of aeration on type 1 piliation were negligible, as were the effects of the above-mentioned drugs in the medium.

\section{DISCUSSION}

The visualization assay permits quantitative determination of the number and length of $F$ pili carried by bacteria. From these variables and the known constant properties of pilus thickness, density and subunit molecular weight, we calculated the mass of the F pili and the number of $F$ pilin subunits on the bacterial surface. We calculated the number of $F$ pilin subunits in the F pili to be $1 \times 10^{5}$ to $2 \times 10^{5}$ copies per cell when the bacteria were grown under optimal conditions. Thus, $F$ pilin is present in approximately the same number as ribosomes (Kjeldgaard \& Gausing, 1974). Since a pool of $F$ pilin has been found in the outer (Beard \& Connolly, 1975) or the inner (Moore et al., 1981) membrane, the total amount of $F$ pilin synthesized may be even higher. In synthetic media, bacterial cells contained only about $0.5 \times 10^{4}$ to $1 \times 10^{4}$ copies of $F$ pilin. The observed number of $F$ pili per cell grown in rich media is in agreement with reports in the literature (Curtiss et al., 1969); however, the average lengths of pili considerably exceed the values given in the literature. The difference in growth conditions and artefactual breakage of $F$ pili in preparing samples for electron microscopic observation may be responsible for the underestimation of the pili length in previous reports. In our experiments high amounts of $F$ pili per cell were retained up to very high cell concentrations. The concentration profile of $F$ pilin for aerated rich medium cultures was quite similar to that obtained by filter tests (Beard et al., 1972). However, bacteria are reported by others (Frost \& Paranchych, 1977) not to carry F pili at high cell densities, thus making preparation of milligram quantities of $F$ pili nearly impossible. We found that electron microscopic observation of pili at these high cell densities was quite difficult since the pili were often obscured by large amounts of other macromolecules excreted by the cells under these conditions. Acidity of the medium due to glucose fermentation $(\mathrm{pH}<6)$ also led to the disappearance of $F$ pili. These factors may explain why $F$ pili were underestimated in previous reports. Purification of the $F$ pili to homogeneity showed that the large amounts of $F$ pili detected by the visualization assay were reasonable - the final yields of purified pili were approximately $25 \%$ of the total amount of $F$ pilin observed in the cultures - and that the large scale preparation of $\mathrm{F}$ pili is possible without the use of overproducing (Helmuth \& Achtman, 1978) $\mathrm{Pil}^{-}$or Fla ${ }^{-}$strains (Helmuth \& Achtman, 1978; Date et al., 1977; Beard et al., 1972). Efficient separation of $F$ pili, type 1 pili and flagella was readily achieved by the method described here, which can be applied to all strains of $E$. coli. Under anaerobic conditions concentration profiles 
of F pili reached a plateau (Brinton \& Beer, 1967; Ippen \& Valentine, 1965). F piliation was lost only after incubation for several days under these conditions.

Under aerobic conditions, $F$ pili disappeared from the surface of bacteria in the late exponential phase of growth. This net loss was not due to breakage or loss of pili into the medium. Digestion of $F$ pili by extracellular enzymes is also unlikely since prolonged incubation of $F$ pili with a culture supernatant had no influence on the appearance of $F$ pili in the fluorescence assay. This disappearance of $F$ pili is in keeping with the hypothesis that $F$ pili can be retracted by the bacteria (Novotny \& Fives-Taylor, 1974). However, direct evidence for a retraction mechanism is lacking. Disappearance of the $\mathrm{F}$ pili from the bacterial surface was noted only in aerated cultures. This observation seems to support the hypothesis that retraction of $F$ pili is directly coupled to oxidative phosphorylation, a proposal based on the finding that drugs which inhibited oxidative phosphorylation also caused pilus retraction (O'Callaghan et al., 1973). We found, however, that aeration was necessary to observe the effects of these drugs. It is thus likely that at least some oxidative phosphorylation is required for retraction. More work is obviously required to clarify the regulation of $F$ piliation and the molecular basis of pilus retraction. One obvious approach is to study the fate of the $\mathrm{F}$ pilin subunits (Achtman et al., 1979) which disappear from the cell surface into the cell or the cell membrane. The very high number of $F$ pilin subunits we found should allow detection of this material after retraction.

We thank Dr M. Eigen for his interest and support and Dr W. Gardiner for critical reading of the manuscript.

\section{REFERENCES}

Achtman, M., ManNing, P., Edelbluthe, E. \& HERRLICH, P. (1979). Export without proteolytic processing of inner and outer membrane proteins encoded by $\mathrm{F}$ sex factor tra. cistrons in Escherichia coli minicells. Proceedings of the National Academy of Sciences of the United States of America 76, 48374841.

Beard, J B. \& Connolly, J. C. (1975). Detection of a protein, similar to the sex pilus subunit in the outer membrane of Escherichia coli cells, carrying a derepressed F-like R factor. Journal of Bacteriology 122, 59-65.

Beard, J. P., Howe, T. G. B. \& Richmond, M. H. (1972). Purification of sex pili from Escherichia coli carrying a derepressed F-like $\mathbf{R}$ factor. Journal of Bacteriology 111, 814-820.

BIEBRICHER, C. K. \& DÜKER, E.-M. (1984). Lightmicroscopic visualization of $F$ and type 1 pili. Journal of General Microbiology 130, 941-949.

Brinton, C. C. (1965). The structure, function, synthesis and genetic control of bacterial pili and a molecular model for DNA and RNA transport in Gram negative bacteria. Transactions of the New York Academy of Sciences 27, 1003-1054.

Brinton, C. C. (1971). The properties of sex pili, the viral nature of "conjugal" genetic transfer systems, and some possible approaches to the control of bacterial drug resistance. Critical Reviews of Microbiology 1, 105-160.

Brinton, C. C. \& BeER, H. (1967). The interaction of male-specific bacteriophages with F-pili. In The Molecular Biology of Viruses, pp. 251-289. Edited by J. C. Colter \& W. Paranchych. New York: Academic Press.

Curtiss, R., Caro, L. G., Allison, D. P. \& Stallions, D. R. (1969). Early stages of conjugation in Escherichia coli. Journal of Bacteriology 100, 10911104.
Date, T., Inuzuka, M. \& Tomoeda, M. (1977). Purification and characterization of F-pili from Escherichia coli. Biochemistry 16, 5579-5585.

Drèze, A. (1960). La stabilité du tryptophane au cours de l'hydrolyse alcaline effectuée en présence d'hydrates de carbone. Bulletin de la Société de chimie biologique 42, 407-417.

Dürwald, H. \& HofFManN-BerLing, H. (1968). Endonuclease I-deficient and ribonuclease I-deficient Escherichia coli mutants. Journal of Molecular Biology 34, 331-346.

Eisenstein, B. I., Beachey, E. H. \& Solomon, S. S. (1981). Divergent effects of cyclic adenosine-3',5'monophosphate on formation of type 1 fimbriae in different K-12 strains of Escherichia coli. Journal of Bacteriology 145, 620-623.

Frost, L. S. \& PARANChYCh, W. (1977). Composition and molecular weight of pili purified from Pseudomonas aeruginosa $\mathrm{K}$. Journal of Bacteriology 131, 259269.

Helmuth, R. \& Achtman, M. (1978). Cell-cell interactions in conjugating Escherichia coli: purification of F pili with biological activity. Proceedings of the National Academy of Sciences of the United States of America 75, 1237-1241.

IPPEN, K. A. \& Valentine, R. C. (1965). An assay for the male substance (F pili) of Escherichia coli K12. Biochemical and Biophysical Research Communications 21, 21-27.

KJELDGaARD, N. O. \& GaUsing, K. (1974). Regulation of biosynthesis of ribosomes. In Ribosomes, pp. 369392. Edited by $M$. Nomura, $A$. Tissières \& $P$. Lengyel. New York: Cold Spring Harbor Laboratory.

Korhonen, T. K., Lounatmaa, K., Ranta, H. \& KuUsi, N. (1980). Characterization of type 1 pili of Salmonella typhimurium LT2. Journal of Bacteriology 144, 800-805. 
LAEMMLI, U. K. (1970). Cleavage of structural proteins during the assembly of the head of bacteriophage T4. Nature, London 227, 660-685.

Maccacaro, G. A. \& Turri, M. (1959). Studi sulle fimbrie batteriche. Osservazioni microelettroforetiche. Giornale di microbiologia 7, 21-36.

Minkley, E. G., Polen, S., BRINTON, C. C. \& IPPENIHLER, K. (1976). Identification of the structural gene for F-pilin. Journal of Molecular Biology 108, 111-121.

MoORe, D., SowA, B. A. \& IPPen-IhleR, K. (1981). Location of an F-pilin pool in the inner membrane. Journal of Bacteriology 146, 251-259.

MoORE, S. (1963). On the determination of cystine as cysteic acid. Journal of Biological Chemistry 238, 235237.

Novotny, C. P. \& Lavin, K. (1971). Some effects of temperature on the growth of $\mathrm{F}$ pili. Journal of Bacteriology 107, 671-682.

Novotny, C. P., Taylor, P. \& Lavin, K. (1972). Effects of growth inhibitors and ultraviolet irradia- tion on F pili. Journal of Bacteriology 112, 10831089.

Novotny, C. P. \& Fives-Taylor, P. (1974). Retraction of F pili. Journal of Bacteriology 117, 1306-1311.

O'Callaghan, R. J., Bundy, L., Bradley, R. \& PARANCHYCH, W. (1973). Unusual arsenate poisoning of the $\mathrm{F}$ pili of Escherichia coli. Journal of Bacteriology 115, 76-81.

Stallions, D. R. \& Curtiss, R. (1972). Bacterial conjugation under anaerobic conditions. Journal of Bacteriology 111, 294-295.

Swaney, L. M., LiU, Y. P., To, Ch. M., To, CH. CH., IPPEN-IHLER, K. \& BRINTON, C. C. (1977). Isolation and characterization of Escherichia coli phase variants and mutants deficient in type 1 pilus production. Journal of Bacteriology 130, 495-505.

Tomoeda, M., Inozuka, M. \& Date, T. (1975). Bacterial sex pili. Progress in Biophysics and $\mathrm{Mol}$ ecular Biology 30, 23-56.

WENDT, L. \& MOBACH, H. W. (1968). Evidence for two states of F pili. Journal of Bacteriology $97,640-646$. 